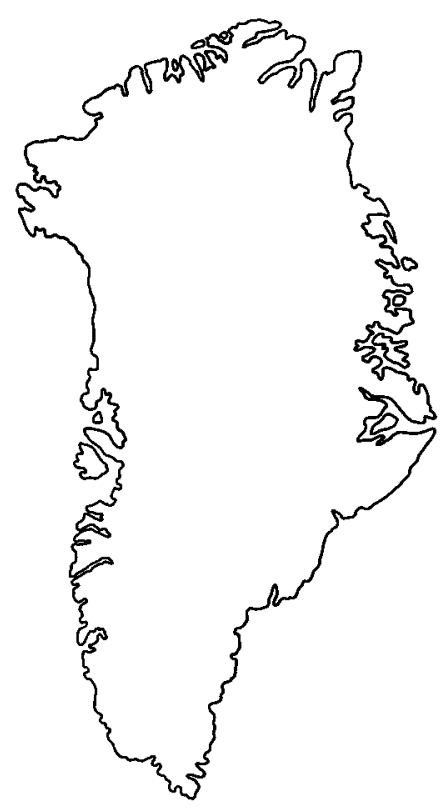

\title{
Palynology of shales associated with the Kap Washington Group volcanics, central North Greenland
}

\author{
D. J. Batten
}

\begin{abstract}
A shale sample from beneath the Kap Washington Group volcanics of central North Greenland failed to yield any microfossils, but an assemblage of Aquilapollenites and other morphologically related triprojectate pollen has been recovered from shales within the upper part of the succession. The relative abundance of these pollen grains and $\mathrm{Rb}-\mathrm{Sr}$ age determinations based on rhyolites suggest that the volcanicity occurred at, or just prior to, the Cretaceous-Tertiary boundary. The presence of Triprojectacites in North Greenland adds further support to recent suggestions of a circumpolar distribution for at least some of the plant species which produced this type of pollen. A non-marine origin for the shales is favoured on the basis of the general aspect of the palynofacies.
\end{abstract}

D. J. B., Department of Geology and Mineralogy, Marischal College, Aberdeen University, Aberdeen AB9 1AS, Scotland, U.K.

The outcrop of the Kap Washington Group volcanics along the northern coast of central North Greenland extends from Lockwood $\varnothing$ in the west to Kap Cannon in the east (fig. 1). These mainly pyroclastic rocks rest conformably on black shales and sandstones whith abundant plant debris in a very fragmented state. Within the upper part of the volcanic sequence, approximately $3 \mathrm{~km}$ above the base, fine-bedded tuff and volcanogenic sediments are interbedded with black shales that also contain plant fragments (Brown \& Parsons, 1981).

The age and character of the Kap Washington Group were discussed recently by Batten $e t$ al. (1981). The morphological features of the fossil leaf fragments in the underlying sediments are consistent with an approximate middle to Late Cretaceous dating, although this determination must be considered tentative (Koch in Batten et al., 1981). A more positive indication of age is provided by palynomorphs isolated from shales interbedded with pyroclastic rocks in the upper part of the sequence. Although the state of preservation of the microfossils is extremely poor, the relative abundance of Aquilapollenites and morphologically related taxa recovered from one of the samples points to a Late Cretaceous (Campanian or Maastrichtian) age for these strata. When coupled with a $\mathrm{Rb}-\mathrm{Sr}$ whole rock isochron date of $63 \pm 2 \mathrm{Ma}$ on 5 rhyolite samples from the volcanic sequence (Larsen et al., 1978), an 


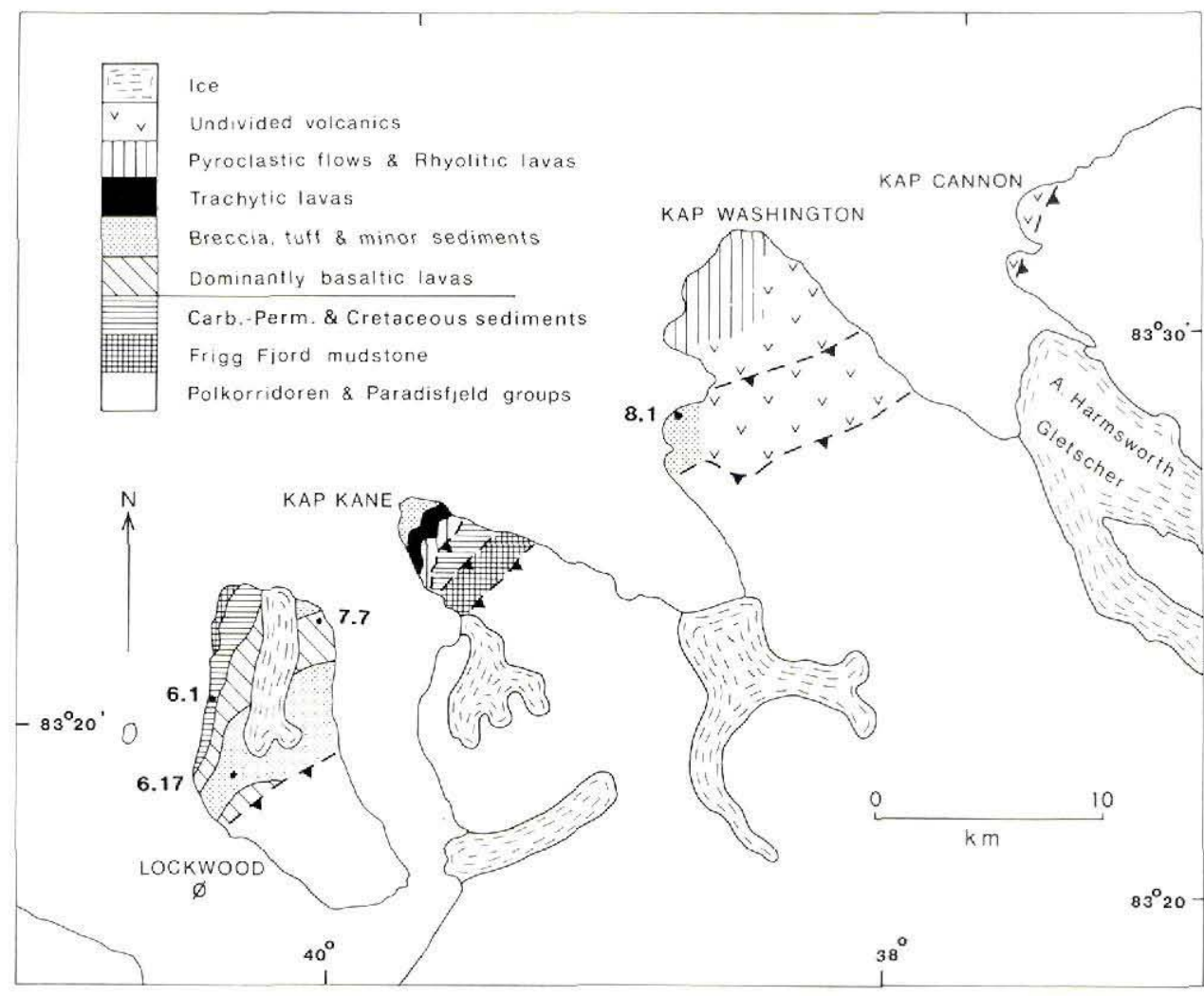

Fig. 1. Geological setting of the Kap Washington Group volcanics, after Brown \& Parsons (1981), indicating sampling localities. Dashed lines with triangles are thrusts.

age for the volcanicity at, or just prior to, the Cretaceous-Tertiary boundary is favoured (Batten et al., 1981).

Both the general aspect of the organic contents of the samples prepared for palynological study from this part of the sequence and the stratigraphic importance of the Aquilapollenites s.l. assemblage are discussed herein in order to amplify statements made in Batten et al., (1981). The significance of the presence of triprojectate pollen in central North Greenland at this time is also considered in the context of the areal extent of the Aquilapollenites palynofloral Province (Batten, 1981a).

\section{Material and methods}

During the summer of 1980, Brown \& Parsons (1981) amassed a large collection of rock specimens while mapping the volcanics of the Kap Washington Group. Most of the sedimentary strata sampled look unpromising from the palynological viewpoint because they are very indurated and thermally altered. As a result, only seven specimens were considered to be worth processing for plant microfossils. All but one of these are from Lockwood $\varnothing$. 
The exception, from locality 8.1, is from beneath the volcanic sequence at Kap Washington itself (fig. 1).

Locality (of Brown \& Parsons), specimen and palynological preparation numbers are as follows:

Locality 6.1, GGU specimen 196653A, preparation MCP1380.

Locality 6.17, GGU specimens 196686 A, B, E, preparations MCP1381, 1382, 1309 (repeated 1383).

Locality 7.7, GGU specimens 196706 and 196742, preparations MCP1384 and 1385.

Locality 8.1, GGU specimen 196744A, preparation MCP1310.

The samples from localities 6.1 and 6.17 are black shales containing an abundance of comminuted indeterminate plant debris and some larger pieces (several cm long) of charcoalified wood. Those from 7.7 are indurated sideritic black shales, and the specimen from 8.1 is a fissile, micaceous medium grey shale bearing unidentified trace fossils (burrows).

Five gm of GGU specimens $196686 \mathrm{E}$ and $196744 \mathrm{~A}$, and $10 \mathrm{gm}$ of the others (including the repeat of $196686 \mathrm{E}$ ) were processed for palynomorphs using hydrochloric and hydrofluoric acids. One kerogen slide was made from each sample after mineral digestion had been completed. Prior to preparing a second slide, the residues were subjected to 2 minutes of oxidation in fuming nitric acid; this was done in a sintered glass funnel fitted to a Buchner flask with hand-bellows attached (Batten, 1981b; Batten \& Morrison, in press). Two preparations, MCP1309 and 1310, were also treated to 2 minutes of vibration in an ultrasonic bath.

GGU 196744A yielded only enough organic matter for two slides, but the other samples were sufficiently organic-rich to allow the remaining residues to be immersed in fuming nitric acid for a further 5 and then another 20 minutes. This additional treatment had little or no discernible effect on the appearance of the palynomorphs, but it did clear some of the unwanted finely divided detritus before third and fourth slides were made.

\section{Organic facies}

GGU 196744A from Kap Washington proved to be organically lean, as implied above. The two slide preparations contain inertinite fragments and some amorphous matter which is probably partly organic.

The other six samples yielded moderate to very large quantities of kerogen. Much of this is in a finely divided, dispersed and aggregated state (particles $<5 \mu \mathrm{m}$ in maximum diameter), but larger, degraded and opaque (mostly inertinite?) fragments are also important (Plate 1, figs 1-4). All components have been thermally altered to the extent that they are now black (6/7-7 on the colour scale of Batten, 1980, 1981b). Some of the debris clearly consists of structured remains of plant tissues (e.g. in MCP1382, from GGU 196686B; Plate 1, figs 1, 2 ), but degradation has been extensive and their original morphological characters are essentially obliterated.

While miospores appear to be present in each of these preparations, they are so poorly preserved that very few can be identified. Practically all positive determinations are from GGU 196686B, but even in this preparation (MCP1382), it has not been possible to establish the identity of the bulk of the microfossils. Apart from the recognition of relatively large 
numbers of specimens as bisaccate pollen and some as triradiate spores, only pollen grains of the Triprojectacites group were identifiable, some to generic level; their distinctive shapes make them easier to recognise than most palynomorphs in a poorly preserved assemblage.

GGU 196686B also yielded more structured plant debris and presumed remains of cuticles than others in this suite. The abundance of organic matter which is clearly derived from land plants in association with numerous aquiloid pollen, bisaccates and other miospores suggests that the sediments accumulated in either a marginal- or non-marine environment. No palynological evidence for marine influence on the environment of deposition was detected, although it is conceivable that dinoflagellate cysts and other marine indicators have been degraded to the point of being unrecognisable. Brown \& Parsons (personal communication) think that the shales within the volcanic sequence may be non-marine.

\section{Triprojectate pollen}

The fossil pollen genus Aquilapollenites Rouse emend. Stanley, 1970, and morphologically related form genera have been the subject of a large number of publications during the past 20 years. Most of the interest in the group has focused on their stratigraphic value and phytogeographic significance. The distinctive morphology of the pollen grains coupled with their rapid evolution during the Late Cretaceous has caused them to be used widely in dating rocks. The restriction of the bulk of the described species to western and Arctic North America and to the West Siberian Plain eastwards to the Soviet Far East, China and Japan, and the relative abundance of representatives of the group in these regions, have played an important part in discussions of floral provinces (Batten, 1981a).

The very degraded state of the North Greenland assemblages makes generic determination of the triprojectate pollen difficult and specific identification virtually impossible. Some specimens are referable to the genera Aquilapollenites Rouse, Mancicorpus Mtchedlishvili and Triprojectus Mtchedlishvili, all as emended by Stanley (1970). A few resemble such species as $A$. attenuatus Funkhouser, $A$. quadrilobus Rouse, $M$. senonicum Mtchedlishvili, $T$. magnus (Mtchedlishvili), Stanley, and T. sentus (Srivastava), Stanley, but the dearth of characters of specific significance renders all comparisons superficial (Plate 1, figs 5-9; Plate 2 , figs $1-7,10,12$ ).

\section{Age of the shales within the Kap Washington Group volcanics}

Despite the taxonomic handicap, the general aspect of the Aquilapollenites assemblage probably indicates a Late Cretaceous (Campanian or Maastrichtian) age for the shales interbedded with the volcanics of the Kap Washington Group (Batten et al., 1981). This suggestion is based mainly on the fact that the triprojectate pollen are relatively abundant and morphologically varied. While the reported stratigraphic range of the Triprojectacites (ignoring age determinations that are unconfirmed or probably incorrect) is Turonian to Eocene, the acme of the group occurred during the latter part of the Late Cretaceous. The demise of the plants which produced the grains appears to have been very rapid during the early Tertiary; most of the pollen species recorded from the Cretaceous are not present in Palaeocene strata. Although a Palaeocene age cannot be entirely discounted, I believe that the North Greenland palynomorphs have more in common with published Late Cretaceous than early Tertiary assemblages. 


\section{Palaeophytogeographic significance of triprojectate pollen in North Greenland}

The Greenland landmass has been considered to have formed a part of the Normapolles palynofloral Province by many palynologists, following the lead of Zaklinskaya (1963). Both Srivastava (1975) and Samoilovich (1977) preferred, however, to include it in the Aquilapollenites Province, basing their decision on the record of a few Aquilapollenites species in the Maastrichtian or early Tertiary (Martin, 1968; Srivastava, 1975) interbasaltic beds which crop out on the island of Mull, western Scotland. Although based on meagre evidence, this interpretation has since been supported by the results of analyses of palynological preparations from Late Cretaceous strata in the northern North Sea, in the North Atlantic west of the Shetlands (Batten, 1981a) and in central West Greenland (Croxton, 1980); samples from all three areas have yielded numerous triprojectate pollen. The assemblages from shelf areas adjacent to northern Britain also contain other taxa which are typically associated with Aquilapollenites both in North America and Siberia.

The occurrence of a Triprojectacites palynoflora in North Greenland provides further evidence in favour of accepting that some of the plant species which produced these pollen grains (as yet of uncertain affinity) were important components of the vegetation in high latitudes in the Northern Hemisphere during the Late Cretaceous, and probably had a circumpolar distribution.

Acknowledgment. I thank the Natural Environment Research Council for a grant in support of my work on Late Cretaceous floral provinces.

\section{References}

Batten, D. J. 1980: Use of transmitted light microscopy of sedimentary organic matter for evaluation of hydrocarbon source potential. Proc. 4th Int. Palynol. Conf., Lucknow (1976-77) 2, 589-594.

Batten, D. J. 1981a: Stratigraphic, palaeogeographic and evolutionary significance of Late Cretaceous and early Tertiary Normapolles pollen. Rev. Palaeobot. Palynol. 35, 125-137.

Batten, D. J. 1981b: Palynofacies, organic maturation and source potential for petroleum. In Brooks, J. (edit.) Organic maturation studies and fossil fuel exploration, 201-223. London: Academic Press.

Batten, D. J., Brown, P. E., Dawes, P. R., Higgins, A. K., Koch, B. Eske, Parsons, I. \& Soper, N. J. 1981: Peralkaline volcanicity on the Eurasia Basin margin. Nature 294, 150-152.

Batten, D. J. \& Morrison, L. in press: Methods of palynological preparation for palaeoenvironmental, source potential and organic maturation studies. Publ. Norwegian Petroleum Directorate.

Brown, P. E. \& Parsons, I. 1981: The Kap Washington Group volcanics. Rapp. Grønlands geol. Unders. 106, 65-68.

Croxton, C. A. 1980: Aquilapollenites from the Late Cretaceous - Paleocene (?) of central West Greenland. Rapp. Grønlands geol. Unders. 101, 5-27.

Larsen, O., Dawes, P. R. \& Soper, N. J. 1978: Rb/Sr age of the Kap Washington Group, Peary Land, North Greenland and its geotectonic implications. Rapp. Grønlands geol. Unders. 90, 115-119.

Martin, A. R. H. 1968: Aquilapollenites in the British Isles. Palaeontology 11, 549-553.

Samoilovich, S. R. 1977: A new outline of the floristic zoning of the Northern Hemisphere in the late Senonian. Paleontol. J. 3, 366-372 (translation from Paleontol Zh. 1977, 3, 118-127).

Srivastava, S. K. 1975: Maastrichtian microspore assemblages from the interbasaltic lignites of Mull, Scotland. Palaeontographica B, 150, 125-156.

Stanley, E. A. 1970: The stratigraphical, biogeographical, paleoautecological and evolutionary significance of the fossil pollen group Triprojectacites. Bull. Georgia Acad. Sci. 28, 1-44.

Zaklinskaya, E. D. 1963: Angiosperm pollen and its significance for Upper Cretaceous and Palaeogene stratigraphy. Trudy Geol. Inst. Akad. Nauk S.S.S.R. 74, 256 pp. (in Russian). 


\section{Plate 1}

Figs $1-4, \times 100$, Figs $5-9, \times 500$

Figs 1,2. Degraded tissues and amorphous finely particulate debris dominate the preparation of GGU specimen 196686B. 1, MCP1382.4, 35.8 127.2; 2, MCP1382.3, 34.1 95.1.

Fig. 3. Palynofacies consisting of a mixture of amorphous debris and larger, solid particles of inertinite; GGU specimen 196686E. MCP1309.2, 124.2 36.0.

Fig. 4. Dense, opaque inertinite fragments dominate the preparation of GGU specimen 196653A, MCP1380.3, 39.0 123.3.

Figs 5-9. Heteropolar Aquilapollenites/Mancicorpus spp. 5, MCP1382.3, 41.0 125.0; 6, MCP1382.4, 51.1 132.3; 7, MCP1382.4, 42.3 123.8; 8, MCP1382.4, 39.4 125.0; 9, MCP1382.4, 47.0 123.9. MGUH 15.925-15.929, from GGU specimen 196686B.

Stage co-ordinates refer to Leitz Dialux microscope number 322, Department of Geology and Mineralogy, Aberdeen University.

\section{Note added in proof}

Since this paper was written, the organic contents of the samples referred to in the explanations of figs. 1-4 (see also p. 17) have been examined by reflectance microscopy. The dominance of inertinite in GGU specimen 196653A is confirmed; only a little vitrinite is present, and this is granular. There is a mixture of inertinite and both granular and mosaic-textured vitrinite in GGU 196686B and E. I am grateful to Dr Patricia Smith (Newcastle University) for this information. 


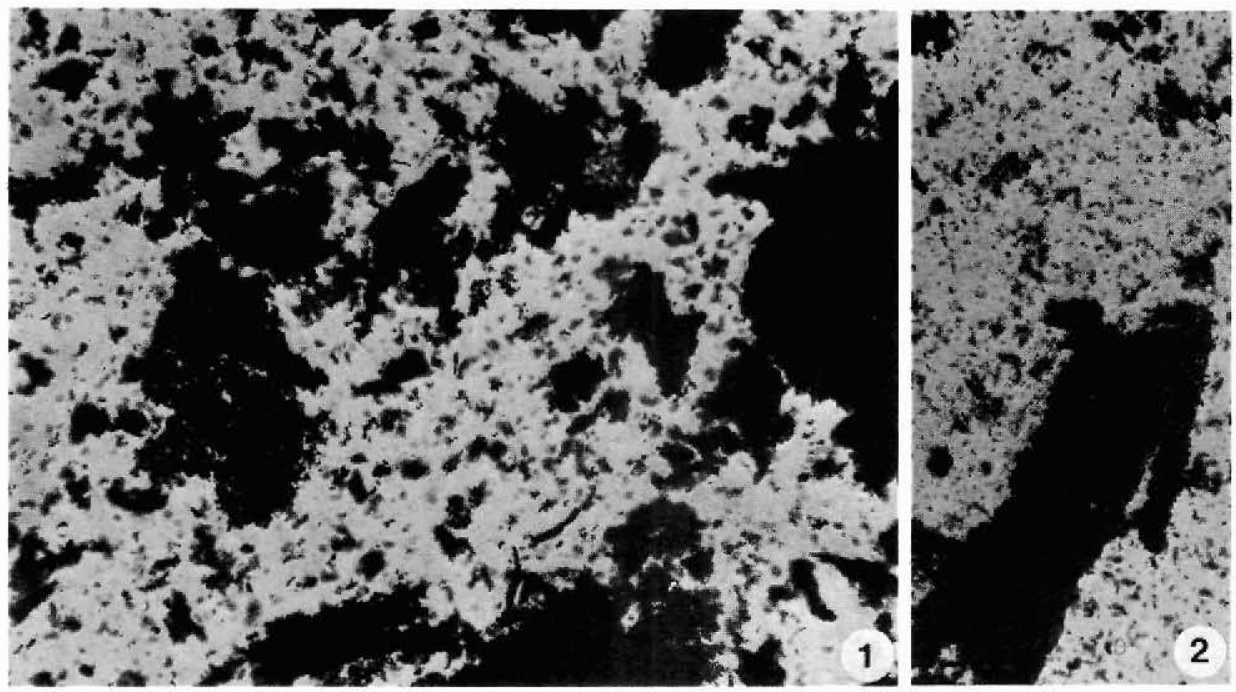

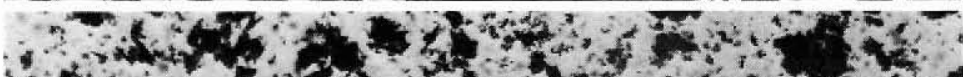
10.

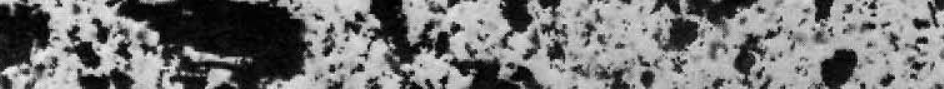

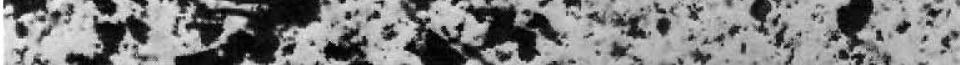

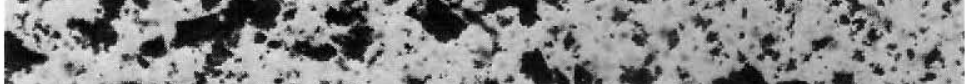

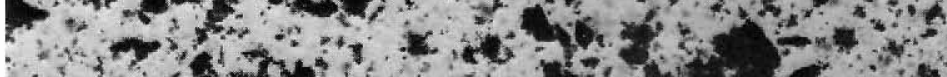

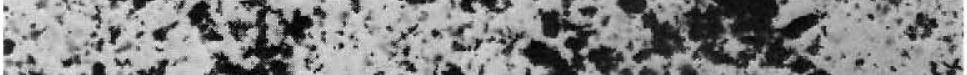

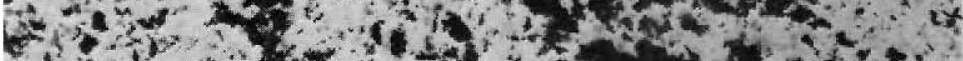

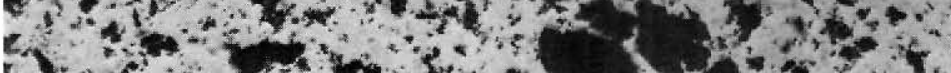

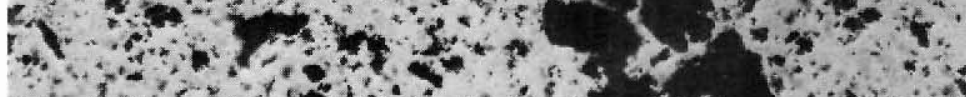

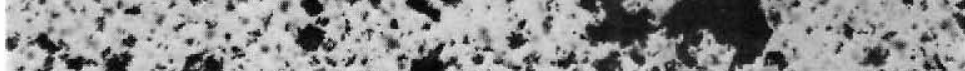

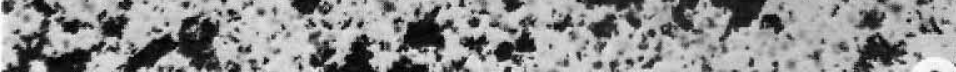

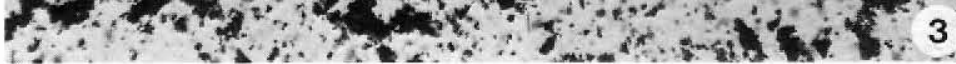

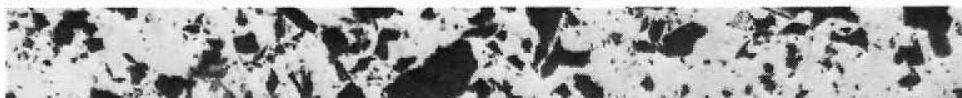

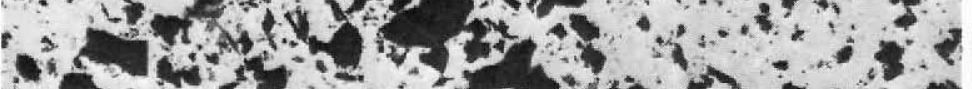

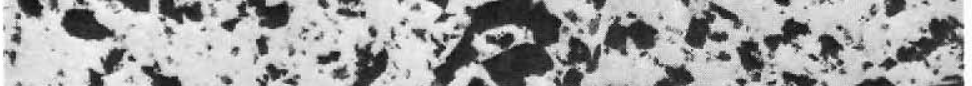

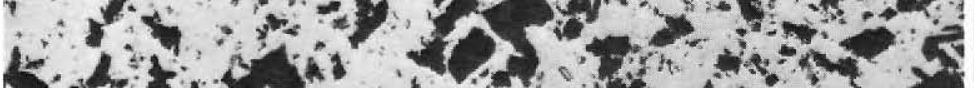

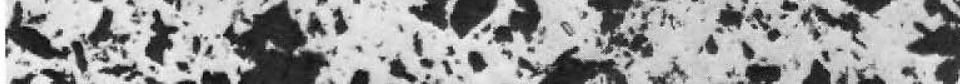

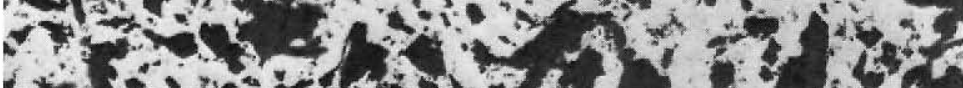

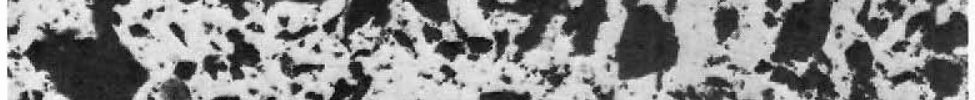

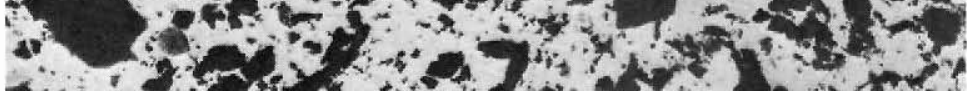

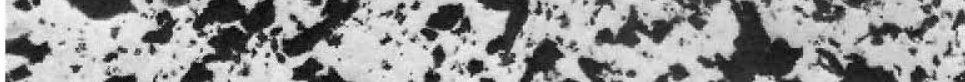

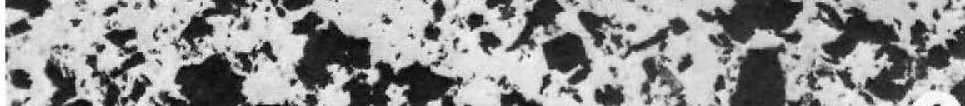

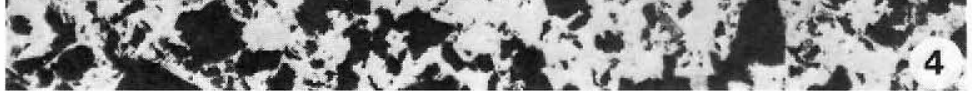
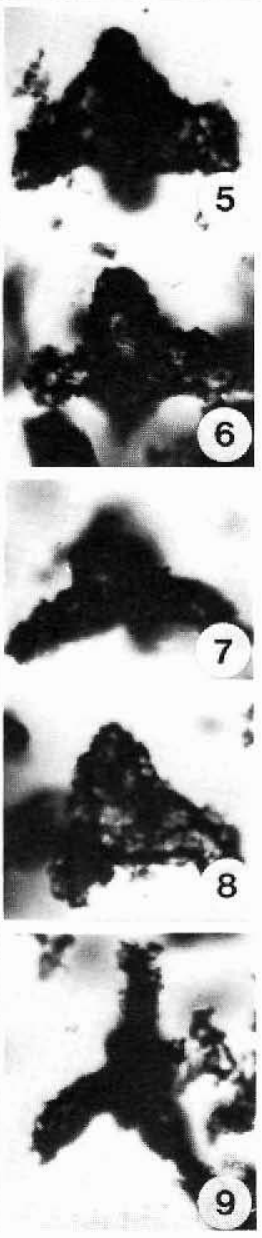


\section{Plate 2}

\section{All magnifications $\times 500$}

Figs 1, 3, 4, 6, 7. Triprojectus spp. 1, MCP1382.1, 31.3 123.8; 3, MCP1382.1, 36.1 136.3; 4, MCP1382.2, 46.1 120.8; 6, MCP1382.2, 31.7 120.5; 7, MCP1382.2, 40.6 125.3. MGUH 15.930, $15.932,15.933,15.935,15.936$.

Fig. 2. ?Aquilapollenites sp. MCP1382.1, 36.0 134.1. MGUH 15.931.

Fig. 5. Aquilapollenites sp. MCP1382.2, 33.8 121.9. MGUH 15.934.

Fig. 8. Sculptured trilete spore. MCP1382.4, 32.1 134.0. MGUH 15.937.

Fig. 9. Smooth walled trilete spore. MCP1380.1, 24.1 119.4. MGUH 15.938.

Fig. 10. Aquilapollenites sp. MCP1382.2, 32.8 128.3. MGUH 15.939.

Figs 11, 13, 14. Bisaccates. 11, MCP1382.2, 29.0 135.0; 13, MCP1382.1, 50.0 128.4; 14, MCP1382.1, 26.1 129.0. MGUH 15.940, 15.942, 15.943 .

Fig. 12. ?Triprojectus sp. MCP1382.2, 27.3 132.7. MGUH 15.941.

Fig. 8 is from GGU specimen 196653A; all other figures are from GGU 196686B. MGUH refers to the type collection, Geological Museum, Copenhagen. 


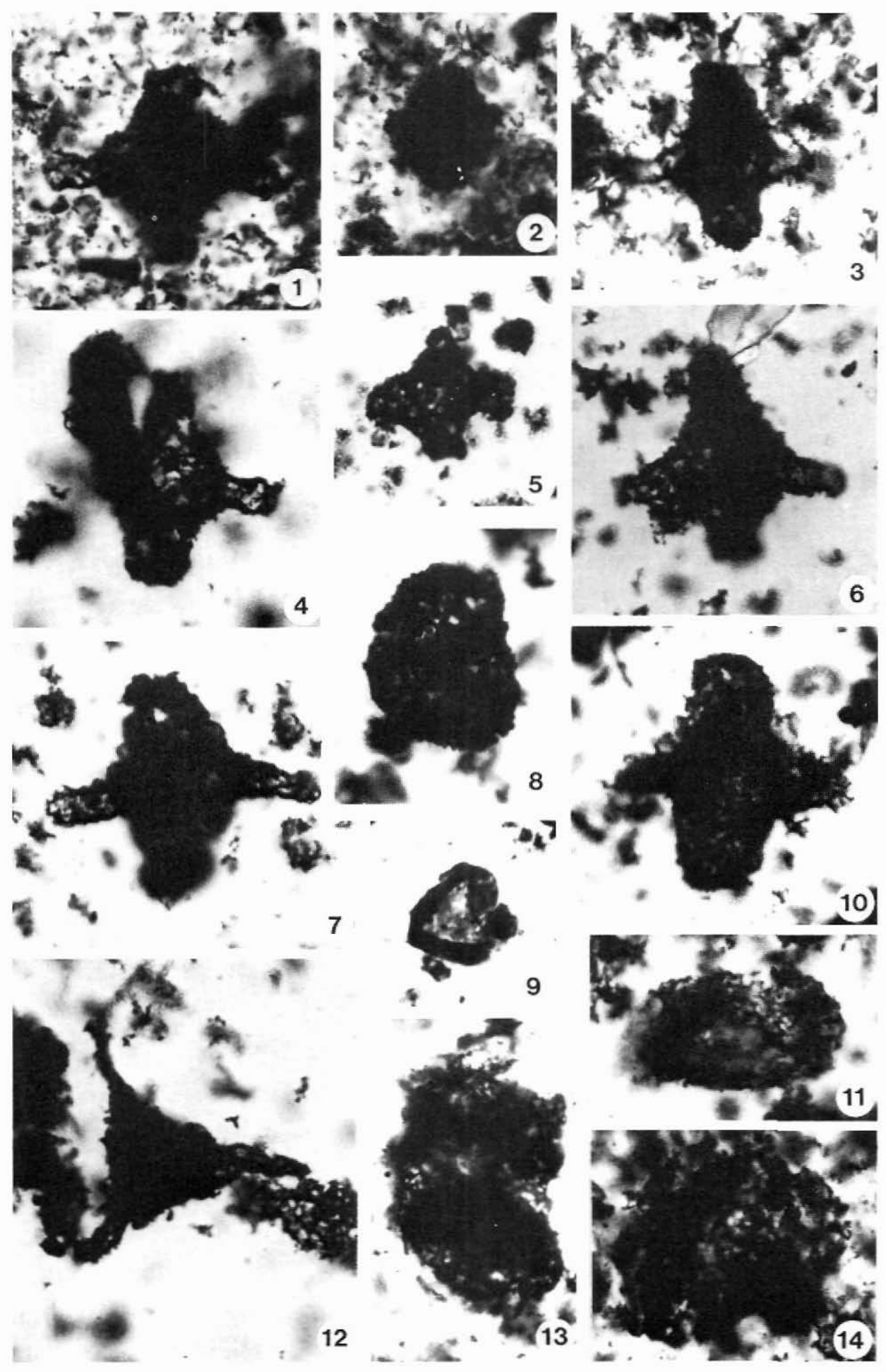

